\title{
EFEITOS DO MEIO DE CULTURA E DA RELAÇÃO BAP/ANA NA MULTIPLICAÇÃO IN VITRO DE CLONES DE Eucalyptus grandis X E. urophylla EM BIORREATOR DE IMERSÃO TEMPORÁRIA ${ }^{1}$
}

\author{
Mila Liparize de Oliveira ${ }^{2}$, Aloisio Xavier ${ }^{3}$, Ricardo Miguel Penchel Filho ${ }^{2}$, Wagner Campos Otoni ${ }^{4}$ e João \\ Batista Teixeira ${ }^{5}$
}

\begin{abstract}
RESUMO - Foram realizados três experimentos individuais com o objetivo de testar diferentes meios de cultura e combinações entre os fitorreguladores BAP e ANA na multiplicação de clones de Eucalyptus grandis x E. urophylla, utilizando o biorreator de imersão temporária RITA ${ }^{\circledR}$. O meio de cultura MS e a frequência de imersão a cada $2 \mathrm{~h}$ promoveram maior massa fresca e número de brotos por explantes. No entanto, houve diferença quanto ao crescimento das culturas entre os dois clones avaliados. A combinação 1,0 $\mu \mathrm{M}$ de BAP com 0,5 $\mu \mathrm{M}$ de ANA foi a que resultou maiores médias em relação à massa fresca e ao número de brotos. As culturas apresentaram alto percentual de hiper-hidricidade, sendo essa desordem fator limitante nas condições deste estudo para o cultivo de Eucalyptus em biorreatores.
\end{abstract}

Palavras-chave: Micropropagação, Clonagem de eucalipto e Biotecnologia.

\section{EFFECTS OF CULTURE MEDIUM AND BAP/NAA RATIO ON IN VITRO MULTIPLICATION OF Eucalyptus grandis $X$ E. urophylla CLONES IN A TEMPORARY IMMERSION BIOREACTOR}

\begin{abstract}
Three individual experiments were conducted in order to test different culture media and BAP/ NAA combinations on the multiplication of E ucalyptus grandis $x$ E. urophylla clones using the temporary immersion bioreactor RITA ${ }^{\circledR}$. The MS medium and the frequency of immersion every two hours promoted the highest fresh weight and number of shoots per explant. However, cultures growth were different between the two clones evaluated. The combination of $1.0 \mu \mathrm{M}$ BAP and $0.5 \mu \mathrm{M}$ NAA promoted the greatest means in relation to fresh weight and number of shoots. The cultures presented high percentages of hyperhydricity and this physiological disorder was a limiting factor in the condition of this study Eucalyptus cultivation in bioreactors.
\end{abstract}

Keywords: Micropropagation, Cloning of eucalyptus and Biotechnology.

\section{INTRODUÇÃO}

Com relação às técnicas de cultivo in vitro de plantas, a micropropagação destaca-se entre aquelas de maior interesse científico e econômico, devido às diversas vantagens que apresenta. A micropropagação em escala comercial depende de elevadas taxas de proliferação durante a fase de multiplicação, aspectos qualitativos das brotações nas fases de enraizamento e aclimatização e alto percentual de sobrevivência das plantas, tudo isso acoplado à automatização de algumas etapas do processo (ZIV, 1995). Nas últimas décadas, equipamentos como biorreatores têm contribuído para a automatização em determinadas fases da micropropagação de algumas espécies de plantas, possibilitando a produção em larga escala.

\footnotetext{
${ }^{1}$ Recebido em 03.02.2010 e aceito para publicação em 31.10.2011.

${ }^{2}$ Fibria Celulose S.A., Jacareí-SP, Brasil. E-mail:<mila.liparize@fibria.com.br>e <rp@fibria.com.br>.

${ }^{3}$ Departamento de Engenharia Florestal, Universidade Federal de Viçosa, UFV, Brasil. E-mail: $<$ xavier@ufv.br $>$.

${ }^{4}$ Universidade Federal de Viçosa, UFV, Brasil. E-mail:<wotoni@ufv.br>.

${ }^{5}$ Embrapa - Recursos Genéticos e Biotecnologia, Brasília, Brasil. E-mail:<batista@cenargen.embrapa.br>.
} 
Para espécies lenhosas como as do gênero Eucalyptus, ainda são escassos os estudos envolvendo a tecnologia de biorreatores. Reis et al. (2003) e McAlister et al. (2005) obtiveram sucesso no desenvolvimento de culturas de eucalipto em biorreator RITA ${ }^{\circledR}$, em relação ao meio semissólido, porém esses autores relataram alta incidência de explantes hiper-hídricos. Castro e González (2002) utilizaram um sistema de imersão temporária adaptado do sistema RITA ${ }^{\circledR}$, com frascos gêmeos, para o cultivo de clones de Eucalyptus grandis, e também constataram incremento nas características de crescimento e viabilidade do uso da técnica, a partir do controle da hiper-hidricidade dos explantes, obtido por meio da incorporação de ar ao recipiente da cultura, manejo dos intervalos de imersão e da composição do meio de cultura. Outros relatos do uso de sistemas de imersão temporária no cultivo de plantas lenhosas são relacionados, principalmente, à embriogênese somática de coníferas (AITKEN-CHRISTIE et al., 1988; GUPTA; TIMMIS, 2005), Hevea brasiliensis (ETIENNE et al., 1997) e café (ETIENNE et al., 2006).

Diversas variáveis podem influenciar na fase de multiplicação, entre elas a composição do meio de cultura utilizado, o ambiente de crescimento e a manipulação do material vegetal durante os subcultivos. Apesar de o objetivo da fase de multiplicação ser a produção do maior número de plantas possível, os aspectos qualitativos dos explantes são de suma importância, entre eles o mínimo de variação dos explantes e homogeneidade da parte aérea produzida, que vão determinar o sucesso nas fases seguintes de enraizamento e aclimatização (GRATTAPAGLIA; MACHADO, 1998).

Diferentes meios básicos de cultura podem ser utilizados na fase de multiplicação, dependendo das necessidades de cada espécie vegetal. Estudos que definem a concentração ótima de citocininas para a multiplicação e suas combinações com outros reguladores são importantes para o ajuste dos meios de cultura (GRATTAPAGLIA; MACHADO, 1998; SANTOSSEREJO et al., 2006).

O uso de biorreatores na fase de multiplicação é alternativa para a micropropagação massal de eucalipto a partir do ajuste de um protocolo de cultivo. Assim, os objetivos deste trabalho foram avaliar diferentes tipos de meios de cultura e relações BAP/ANA no meio MS, na micropropagação de clones de Eucalyptus grandis $x$ E. urophylla, utilizando biorreatores de imersão temporária RITA ${ }^{\circledR}$.

\section{MATERIAL E MÉTODOS}

\subsection{Fonte, meio de cultura e condições de cultivo dos explantes}

Os experimentos foram desenvolvidos no Laboratório de Biotecnologia do Centro de Tecnologia - CT da empresa Fibria Celulose (antiga Aracruz Celulose S. A.), localizada no município de Aracruz, Espírito Santo.

O material vegetal utilizado para introdução nos biorreatores foram clones de Eucalyptus grandis $x$ E. urophylla (C1 e C2), provenientes da empresa Fibria, preestabelecidos in vitro por meio da micropropagação em meio de cultura semissólido. Foram cultivados em placas de Petri estéreis e descartáveis (Pleion Bioplass ${ }^{\circledR}$ ), de 90 mm de diâmetro(D) x 15 mm(H) de altura(Figura 1A), contendo $25 \mathrm{~mL}$ do meio de cultura MS (MURASHIGE; SKOOG, 1962), adicionado de $100 \mathrm{mg} \mathrm{L}^{-1}$ de mioinositol $\left(\right.$ Sigma $\left.^{\circledR}\right), 10 \mathrm{mg} \mathrm{L}^{-1}$ de tiamina-HCl $\left(\right.$ Sigma $\left.^{\circledR}\right), 0,50 \mathrm{mg} \mathrm{L}^{-1}$ de ácido nicotínico $\left(\operatorname{Sigma}^{\circledR}\right), 0,50 \mathrm{mg} \mathrm{L}^{-1}$ de piridoxina$\mathrm{HCl}\left(\right.$ Sigma $^{\circledR}$ ), $100 \mathrm{mg} \mathrm{L}^{-1}$ de L-glutamina (Sigma ${ }^{\circledR}$ ), 0,34 $\mathrm{mg} \mathrm{L}^{-1}$ de BAP (6-benzilaminopurina - Sigma ${ }^{\circledR}$ ), 0,01 $\mathrm{mg} \mathrm{L}^{-1}$ de ANA (ácido naftalenoacético - Sigma ${ }^{\circledR}$ ), $30 \mathrm{~g} \mathrm{~L}^{-1}$ de sacarose (Vetec ${ }^{\circledR}$ ) e $7 \mathrm{~g} \mathrm{~L}^{-1}$ de bacto-ágar $\left(\mathrm{BD}^{\circledR}\right)$. O pH foi ajustado para 5,8 com KOH (1 N) e HCl ( $1 \mathrm{~N}$ ) antes da adição do ágar e da esterilização em autoclave a uma pressão de 1,5 atm e temperatura de $121^{\circ} \mathrm{C}$ por 15 min. O material vegetal foi estabelecido em prateleiras de metal aramado com iluminações vertical e lateral, acondicionado em sala de cultura a $24 \pm 2{ }^{\circ} \mathrm{C}$, fotoperíodo de $14 \mathrm{~h}$ e irradiância PAR média de $20 \mu \mathrm{mol} \mathrm{m} \mathrm{m}^{-2} \mathrm{~s}^{-1}$, medida no aparelho Optic Science - Modelo DQM.

\subsection{Multiplicação em biorreator: meio de cultura MS e WPM}

Neste experimento, foram testados os meios de cultura MS (MURASHIGE; SKOOG, 1962) e WPM (LLOYD; McCOWN, 1980) e duas frequências de imersão, de 2 e $4 \mathrm{~h}$ por um período de $10 \mathrm{seg}$, na fase de multiplicação em biorreator de imersão temporária RITA ${ }^{\circledR}$ (Vitropic SA).

Foram utilizados brotos apicais, com massa fresca e tamanho uniformes, como explantes iniciais de um clone de Eucalyptus grandis x E. urophylla (C1), estabelecidos in vitro (Figura 1B). Os explantes foram pré-cultivados, aproximadamente, sete dias antes de sua utilização nos biorreatores RITA $^{\circledR}$ para 

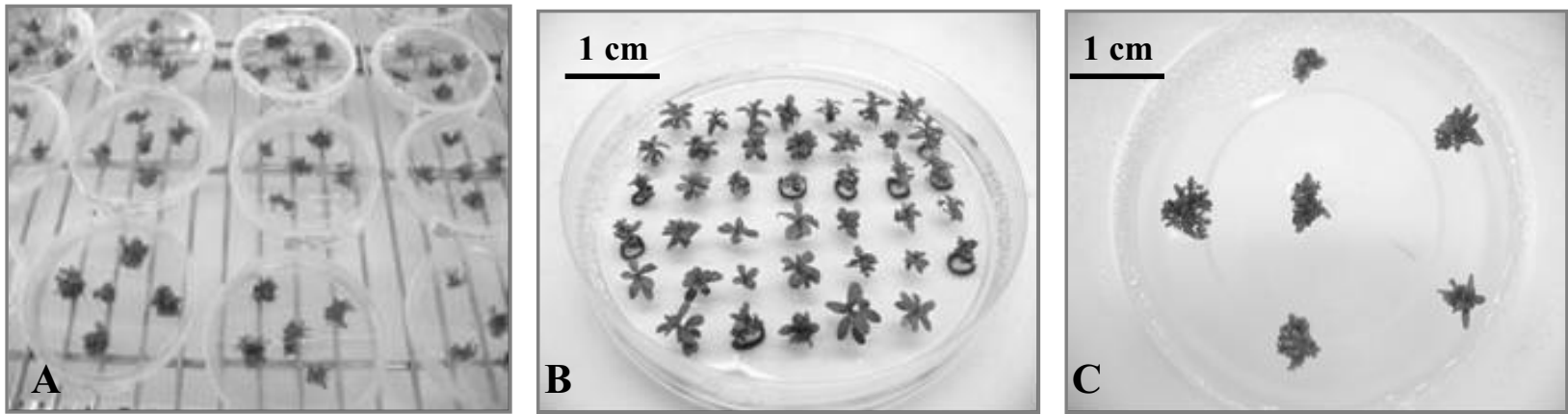

Figura 1 - Banco clonal in vitro (A), brotos apicais (B) e tufos de multibrotações (C) dos clones de Eucalyptus grandis $x$ E. urophylla utilizados como explantes iniciais no cultivo em biorreatores de imersão temporária RITA ${ }^{\circledR}$.

Figure 1 - In vitro clonal bank (A), apical buds (B) and nodal bunches (C) of Eucalyptus grandis $x$ E. urophylla clones used as initial explants in RITA ${ }^{\circledR}$ temporary immersion bioreactors cultivation.

experimentação, permanecendo em placas de Petri contendo meio MS, como descrito no item 2.1, sem adição de reguladores de crescimento.

Aos dois meios básicos de cultura testados foram adicionados $100 \mathrm{mg} \mathrm{L}^{-1}$ de mioinositol, $10 \mathrm{mg} \mathrm{L}^{-1}$ de tiamina-HCl, 0,50 mg L ${ }^{-1}$ de ácido nicotínico, 0,50 $\mathrm{mg} \mathrm{L}^{-1}$ de piridoxina- $\mathrm{HCl}, 0,11 \mathrm{mg} \mathrm{L}^{-1}$ de BAP e $30 \mathrm{~g} \mathrm{~L}^{-1}$ de sacarose, com pH ajustado para 5,8 com KOH (1 N) e $\mathrm{HCl}(1 \mathrm{~N})$, antes da esterilização em autoclave a uma pressão de 1,5 atm e temperatura de $121^{\circ} \mathrm{C}$ por $15 \mathrm{~min}$. Utilizou-se o volume de $200 \mathrm{~mL}$ de meio de cultura líquido por recipiente, o qual foi autoclavado diretamente dentro dos recipientes dos biorreatores. Após a introdução nos biorreatores, o material vegetal foi acondicionado em sala de cultura a $24 \pm 2{ }^{\circ} \mathrm{C}$, fotoperíodo de 14 h e irradiância média de $20 \mu \mathrm{mol} \mathrm{m} \mathrm{m}^{-2} \mathrm{~s}^{-1}$. Como suporte de apoio para os explantes dentro dos biorreatores, utilizou-se disco de esponja polimérica (Bulpren S 28133, densidade de $30 \mathrm{~kg} \mathrm{~m}^{-3}$ ) sob papel-filtro qualitativo ( $\mathrm{N}^{\mathrm{o}} 1$ - Qualy $\left.{ }^{\circledR}\right)$.

O delineamento experimental utilizado foi o inteiramente casualizado, em arranjo fatorial 2 x 2, sendo dois meios básicos de cultura (MS e WPM) e duas frequências de imersão (2 e 4 h), com cinco repetições por tratamento, cada uma constituída por um recipiente RITA $^{\circledR}$ contendo oito explantes.

Para avaliação da massa fresca, foi realizada a pesagem dos grupos de explantes de cada repetição dos tratamentos aos 0 e 28 dias de idade da cultura. O número de brotos foi obtido pela contagem de novos brotos com dois ou mais pares de folhas desenvolvidos durante o ciclo de cultivo, em todos os explantes, aos 28 dias de idade da cultura. O percentual de hiper-hidricidade foi obtido através da análise visual do grupo de oito explantes de cada repetição, atribuindo-se valores de 0 a 100, aos 0 e 28 dias de idade da cultura.

\subsection{Multiplicação em biorreator: meio de cultura MS, QL e JADS}

Este experimento avaliou os meios de cultura MS (MURASHIGE; SKOOG, 1962), JADS (CORREIA, 1995) e QL (QUOIRIN; LEPOIVRE, 1977), na fase de multiplicação de dois clones de Eucalyptus grandis $x$ E. urophylla (C1 e C2). Como explantes iniciais, para introdução nos biorreatores RITA ${ }^{\circledR}$, foram utilizados tufos de multibrotações, estabelecidos in vitro (Figura 1C), com massa fresca e tamanho uniformes.

Aos meios básicos de cultura foram adicionados $100 \mathrm{mg} \mathrm{L}^{-1}$ de mioinositol, $10 \mathrm{mg} \mathrm{L}^{-1}$ de tiamina-HCl, 0,50 $\mathrm{mg} \mathrm{L}^{-1}$ de ácido nicotínico, 0,50 $\mathrm{mg} \mathrm{L}^{-1}$ de piridoxina$\mathrm{HCl}, 0,11 \mathrm{mg} \mathrm{L}^{-1}$ de BAP e $30 \mathrm{~g} \mathrm{~L}^{-1}$ de sacarose, com $\mathrm{pH}$ ajustado para 5,8 com $\mathrm{KOH}(1 \mathrm{~N})$ e $\mathrm{HCl}(1 \mathrm{~N})$ antes da esterilização em autoclave a uma pressão de 1,5 atm e temperatura de $121^{\circ} \mathrm{C}$ por $15 \mathrm{~min}$. Utilizou-se o volume de $250 \mathrm{~mL}$ de meio por recipiente, o qual foi autoclavado diretamente dentro dos recipientes dos biorreatores. Após a introdução nos biorreatores, o material vegetal foi acondicionado em sala de cultura a $24 \pm 2{ }^{\circ} \mathrm{C}$, fotoperíodo de $14 \mathrm{~h}$ e irradiância PAR média de $20 \mu \mathrm{mol} \mathrm{m} \mathrm{m}^{-2} \mathrm{~s}^{-1}$.

A frequência de imersão utilizada foi de $2 \mathrm{~h}$ por um período de $8 \mathrm{seg}$, e como suporte de apoio para os explantes dentro dos biorreatores utilizou-se disco de esponja polimérica (Bulpren S 28133, densidade de $30 \mathrm{~kg} \mathrm{~m}^{-3}$ ) sob papel-filtro qualitativo ( $\mathrm{N}^{\mathrm{o}} 1$ - Qualy ${ }^{\circledR}$ ).

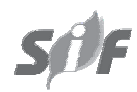

Revista Árvore, Viçosa-MG, v.35, n.6, p.1207-1217, 2011 
O delineamento experimental utilizado foi o inteiramente casualizado, em arranjo fatorial $3 \times 2$, sendo três meios básicos de cultura (MS, JADS e QL) e dois materiais genéticos (C1 e C2), com quatro repetições por tratamento, cada uma constituída por um recipiente RITA ${ }^{\circledR}$ contendo quatro explantes.

Para avaliação da massa fresca, foi realizada a pesagem do grupo de explantes de cada repetição dos tratamentos, aos 0 e 21 dias de idade da cultura. O número de brotos foi obtido pela contagem dos brotos principais (saindo diretamente da base do explante) com dois ou mais pares de folhas, em todos os explantes, aos 0 e 21 dias de idade da cultura. O percentual de hiper-hidricidade foi obtido por meio da análise visual do explante, com a contagem do número de brotos hiper-hídricos em cada explante, aos 0 e 21 dias de idade da cultura.

\subsection{Multiplicação em biorreator: relação BAP/ANA}

Este experimento avaliou 12 diferentes combinações entre os fitorreguladores BAP/ANA: T1 = 0,0/0,0; $\mathrm{T} 2=0,0 / 0,05 ; \mathrm{T} 3=0,0 / 0,5 ; \mathrm{T} 4=0,5 / 0,0 ; \mathrm{T} 5=0,5 / 0,05$; $\mathrm{T} 6=0,5 / 0,5 ; \mathrm{T} 7=1,0 / 0,0 ; \mathrm{T} 8=1,0 / 0,05 ; \mathrm{T} 9=1,0 / 0,5 ;$ $\mathrm{T} 10=1,5 / 0,0 ; \mathrm{T} 11=1,5 / 0,05 ; \mathrm{e} \mathrm{T} 12=1,5 / 0,5 \mu \mathrm{M}$. Foram utilizados brotos apicais (Figura 1B), com massa fresca e tamanho uniformes, como explantes iniciais de um clone de Eucalyptus grandis x E. urophylla (C1), estabelecidos in vitro, pré-cultivados, aproximadamente sete dias antes de sua utilização nos biorreatores RITA ${ }^{\circledR}$ para experimentação, permanecendo em placas de Petri contendo meio MS, como descrito no item 2.1, sem adição de reguladores de crescimento.

As combinações foram testadas em meio MS adicionado de $100 \mathrm{mg} \mathrm{L}^{-1}$ de mioinositol, $10 \mathrm{mg} \mathrm{L}^{-1}$ de tiamina-HCl, 0,50 $\mathrm{mg} \mathrm{L}^{-1}$ de ácido nicotínico, 0,50 $\mathrm{mg} \mathrm{L}^{-1}$ de piridoxina-HCl e $30 \mathrm{~g} \mathrm{~L}^{-1}$ de sacarose, com $\mathrm{pH}$ ajustado para 5,8 com KOH (1 N) e HCl (1 N) antes da esterilização em autoclave a uma pressão de 1,5 atm e temperatura de $121^{\circ} \mathrm{C}$ por $15 \mathrm{~min}$. Utilizou-se o volume de $250 \mathrm{~mL}$ de meio de cultura por recipiente, o qual foi autoclavado diretamente dentro dos recipientes dos biorreatores. Após a introdução nos biorreatores, o material vegetal foi acondicionado em sala de cultura a $24 \pm 2{ }^{\circ} \mathrm{C}$, fotoperíodo de 14 h e irradiância PAR média de $20 \mu \mathrm{mol} \mathrm{m} \mathrm{m}^{-2} \mathrm{~s}^{-1}$.

A frequência de imersão utilizada foi de $2 \mathrm{~h}$ por um período de 8 seg, e como suporte de apoio para os explantes dentro dos biorreatores utilizou-se disco de esponja polimérica (Bulpren S 28133, densidade de $30 \mathrm{~kg} \mathrm{~m}^{-3}$ ) sob papel-filtro qualitativo ( $\mathrm{N}^{\mathrm{o}} 1-$ Qualy $^{\circledR}$ ).
O delineamento experimental utilizado foi o inteiramente casualizado, com 12 tratamentos (combinações de BAP/ANA) e 20 repetições por tratamento, sendo cada repetição constituída por um explante e cada tratamento formado por dois recipientes RITA $^{\circledR}$ contendo 10 explantes.

Para avaliação da massa fresca, foi realizada a pesagem dos explantes aos 0 e 23 dias de idade da cultura. O número de brotos foi obtido pela contagem de novos brotos, com dois ou mais pares de folhas, desenvolvidos durante o ciclo de cultivo, em cada explante, aos 23 dias de idade da cultura. O percentual de hiper-hidricidade foi obtido através da análise visual do explante, com a contagem do número de brotos hiper-hídricos em cada explante, aos 0 e 23 dias de idade da cultura.

\section{RESULTADOS}

\subsection{Multiplicação em biorreator: meios de cultura MS e WPM}

O fator frequência de imersão apresentou diferença em relação à característica massa fresca dos explantes, número de brotos e de hiper-hidricidade, sendo a frequência de $2 \mathrm{~h}$ superior à de $4 \mathrm{~h}$ em ambos os meios de cultura avaliados (Figura 2). Os explantes dos tratamentos constituídos pelo meio de cultura WPM, de modo geral, apresentaram menor vigor em relação ao meio de cultura MS, com coloração avermelhada do caule e calosidades nas folhas (Figura 3). Para o porcentual de hiper-hidricidade dos explantes, na frequência de 2 h, obteve-se maior percentual de hiperhidricidade dos explantes nos meios MS (88\%) em comparação com o WPM (60\%). Já na frequência de 4 h o meio WPM apresentou maior percentual de hiperhidricidade (32\%) do que o meio MS (24\%) (Figura 2C).

\subsection{Multiplicação em biorreator: meios de cultura MS, QL e JADS}

O C1 apresentou médias de massa fresca superiores ao C2 em dois dos três meios de cultura estudados (MS e QL) (Figura 4A). No C1, o meio MS tendeu a uma superioridade em relação aos demais, com média de 0,43 g, seguido pelo QL com 0,33 g e pelo JADS com 0,19 g por explante avaliado. Quanto à característica número de brotos, também o C1 foi superior ao C2 na produção de novos brotos durante o período de cultivo, com média de 11 brotos por explante, em comparação com a 5,3 do C2. Em relação aos meios de cultura estudados, o meio MS teve tendência de superioridade, 

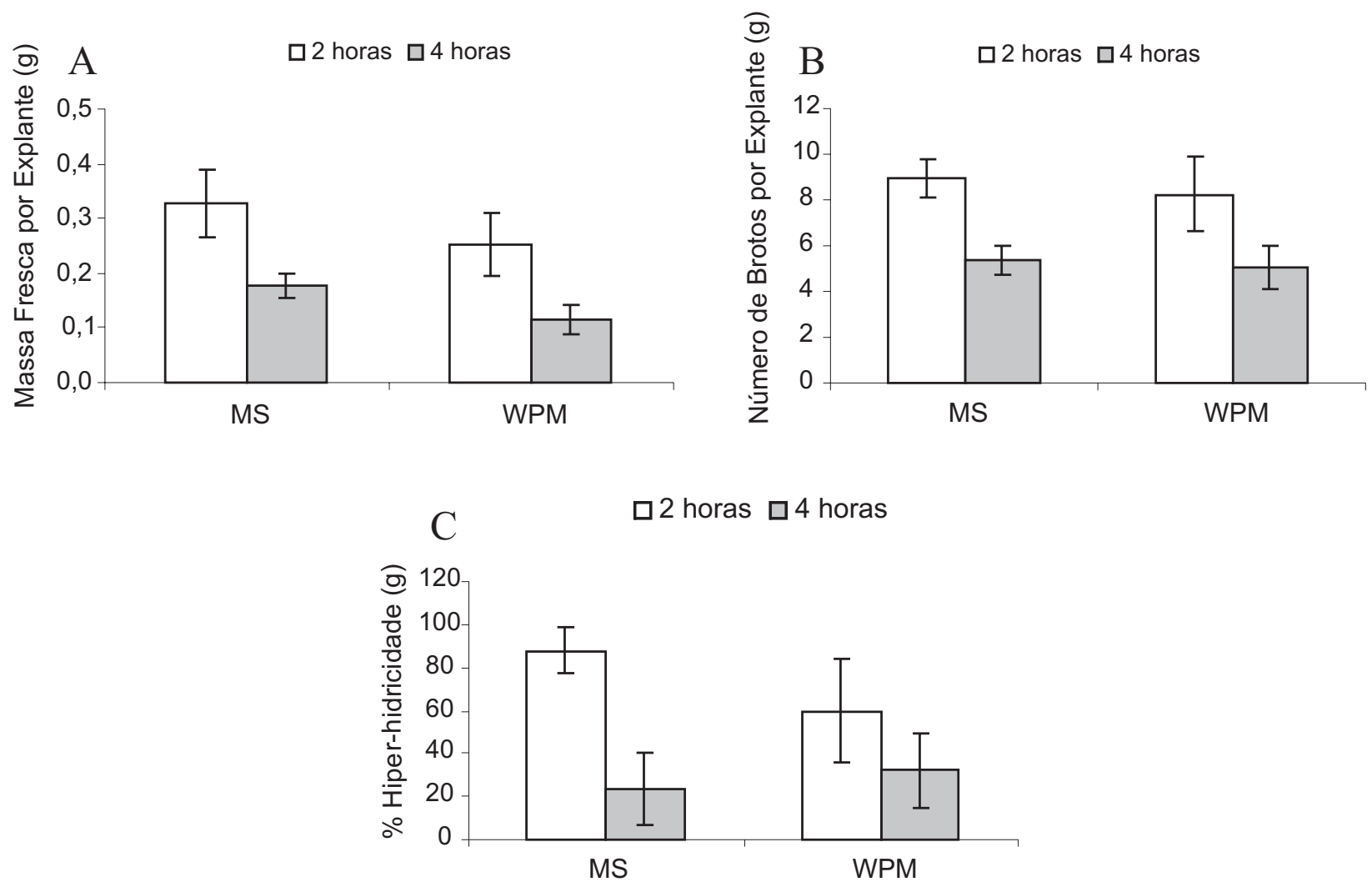

Figura 2 - Massa fresca (A), número de brotos (B) e percentual de hiper-hidricidade (C) de explantes cultivados em meios de cultura MS e WPM, nas duas frequências de imersão estudadas (2 e 4 h), aos 28 dias de idade da cultura do clone de Eucalyptus grandis x E. urophylla (C1) em biorreatores de imersão temporária RITA ${ }^{\circledR}$. Barras verticais indicam o erro-padrão da média.

Figure 2 - Fresh weight (A), number of shoots (B) and hyperhydricity percentage (C) of explants grown in MS and WPM medium, in the two immersion frequencies studied ( 2 and $4 \mathrm{~h}$ ) at 28 days of age of the culture of Eucalyptus grandis $x$ E. urophylla clone (C1) in RITA ${ }^{\circledR}$ temporary immersion bioreactors. Vertical bars indicate the standard error of the mean.
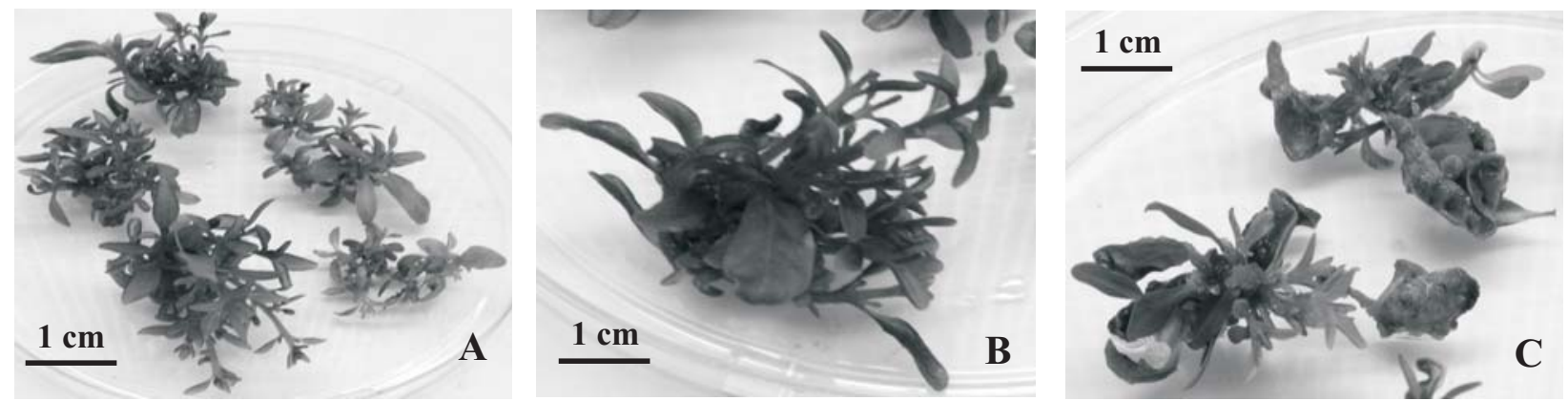

Figura 3 - Brotações do clone de Eucalyptus grandis x E. urophylla (C1) cultivados em biorreator de imersão temporária RITA $^{\circledR}$ : tufos de multibrotações, com maior vigor em meio de cultura MS (A) e apresentando coloração avermelhada no caule (B) e calosidade nas folhas (C) em meio WPM, aos 28 dias de idade.

Figure 3 - Shoots of Eucalyptus grandis $x$ E. urophylla clone (C1) grown in RITA ${ }^{\circledR}$ temporary immersion bioreactor: tufts of nodal, with greater force on MS medium (A) and presenting a reddish color on the stem (B) and callus in leaves (C) in WPM culture medium, at 28 days of age. 
com número médio de brotos de 12,7 (MS), 11,6 (QL) e 8,6 (JADS) para o C1 e 5,6 (MS), 5,3 (JADS) e 4,9 (QL) para o C2 (Figura 4B). Em relação à característica hiper-hidricidade, esta apresentou diferença entre clones, tendo o C2 mostrado maior percentual de hiperhidricidade dos explantes quando cultivado em meio de cultura QL e JADS (Figura 4C), no entanto, no meio MS, não se notou diferença de resposta entre os dois clones avaliados.

\subsection{Multiplicação em biorreator: relação BAP/ANA}

Houve diferença significava $(\mathrm{P}<0,05)$ entre as combinações de BAP/ANA estudadas com relação a todas as características avaliadas. Para massa fresca dos explantes, os tratamentos T5 (0,5/0,05), T9 $(1,0 / 0,5)$ e T12 $(1,5 / 0,5)$ foram semelhantes, e o T9 apresentou maior média de massa fresca nesse experimento $(0,137 \mathrm{~g})$. Os grupos de tratamentos T6 $(0,5 / 0,5)$, T7 $(1,0 / 0,0)$, T8 (1,0/0,05), T10 (1,5/0,0) е T11 (1,5/0,05) e T1 $(0,0 / 0,0)$, T2 $(0,0 / 0,05)$, T3 $(0,0 / 0,5)$ e T4 $(0,5 / 0,0)$ não foram significativamente diferentes entre si, sendo neste último grupo obtidas as menores médias de massa fresca (Figura 5A). Com relação ao número de brotos, a maior média também foi encontrada no T9 $(4,25)$, no entanto este tratamento foi estatisticamente semelhante aos T4, T5, T6, T7, T8, T10, T11 e T12, diferindo somente de T1, T2 e T3, que apresentaram as menores médias de produtividade dos explantes e onde a concentração de BAP foi igual
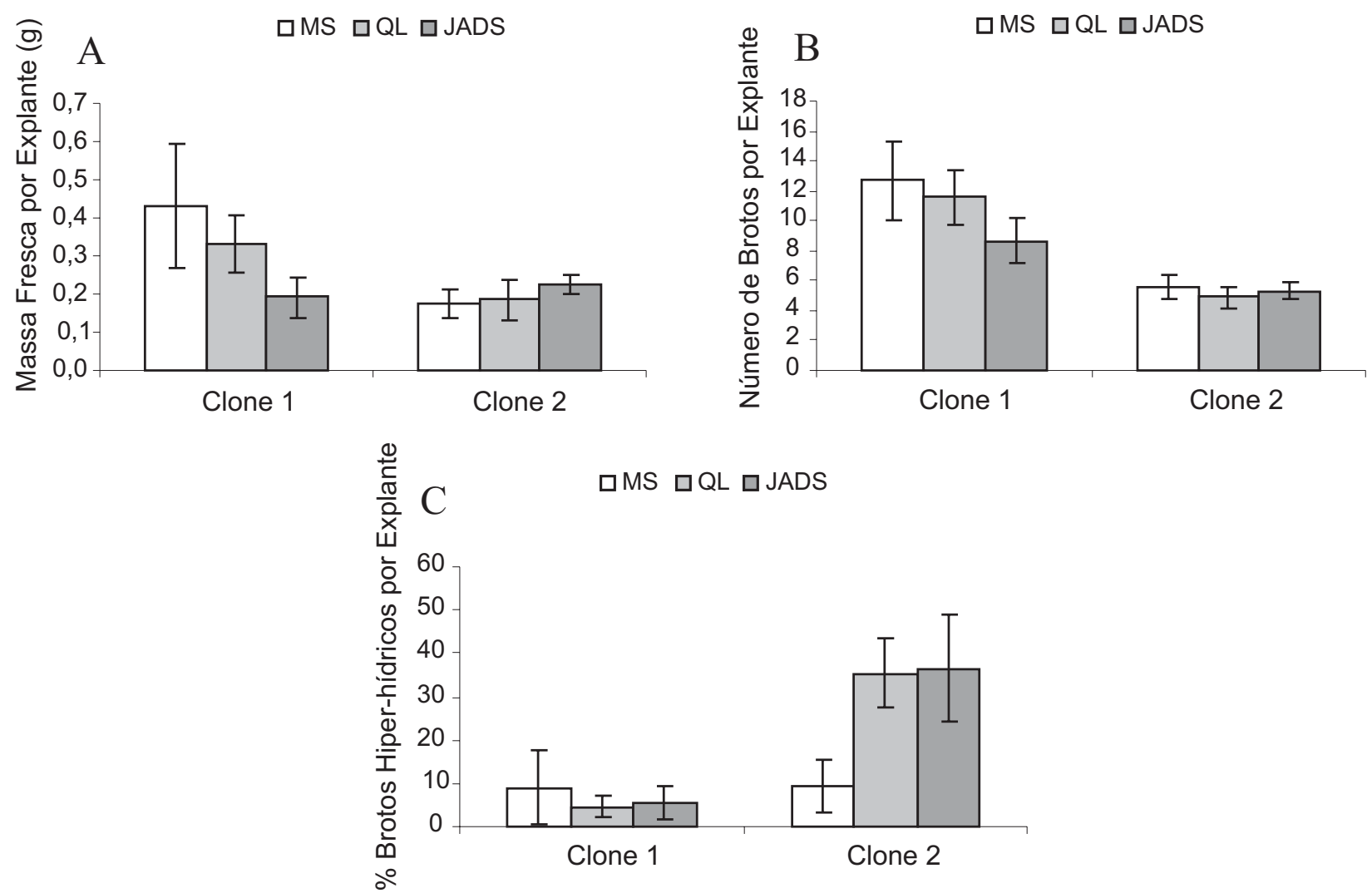

Figura 4 - Massa fresca (A), número de brotos (B) e percentual de hiper-hidricidade (C) por explante dos dois clones de Eucalyptus grandis $x$ E. urophylla (C1 e C2) e dos três meios de cultura estudados, aos 21 dias de cultivo em biorreatores de imersão temporária RITA ${ }^{\circledR}$. Barras verticais indicam o erro-padrão da média.

Figure 4-Fresh weight (A), number of shoots (B) and hyperhydricity percentage (C) per explant for two Eucalyptus grandis $x$ E. urophylla clones (C1 and C2) and three culture media studied, at 21 days of cultivation in RITA ${ }^{\circledR}$ temporary immersion bioreactors. Vertical bars indicate the standard error of the mean.

Revista Árvore, Viçosa-MG, v.35, n.6, p.1207-1217, 2011 

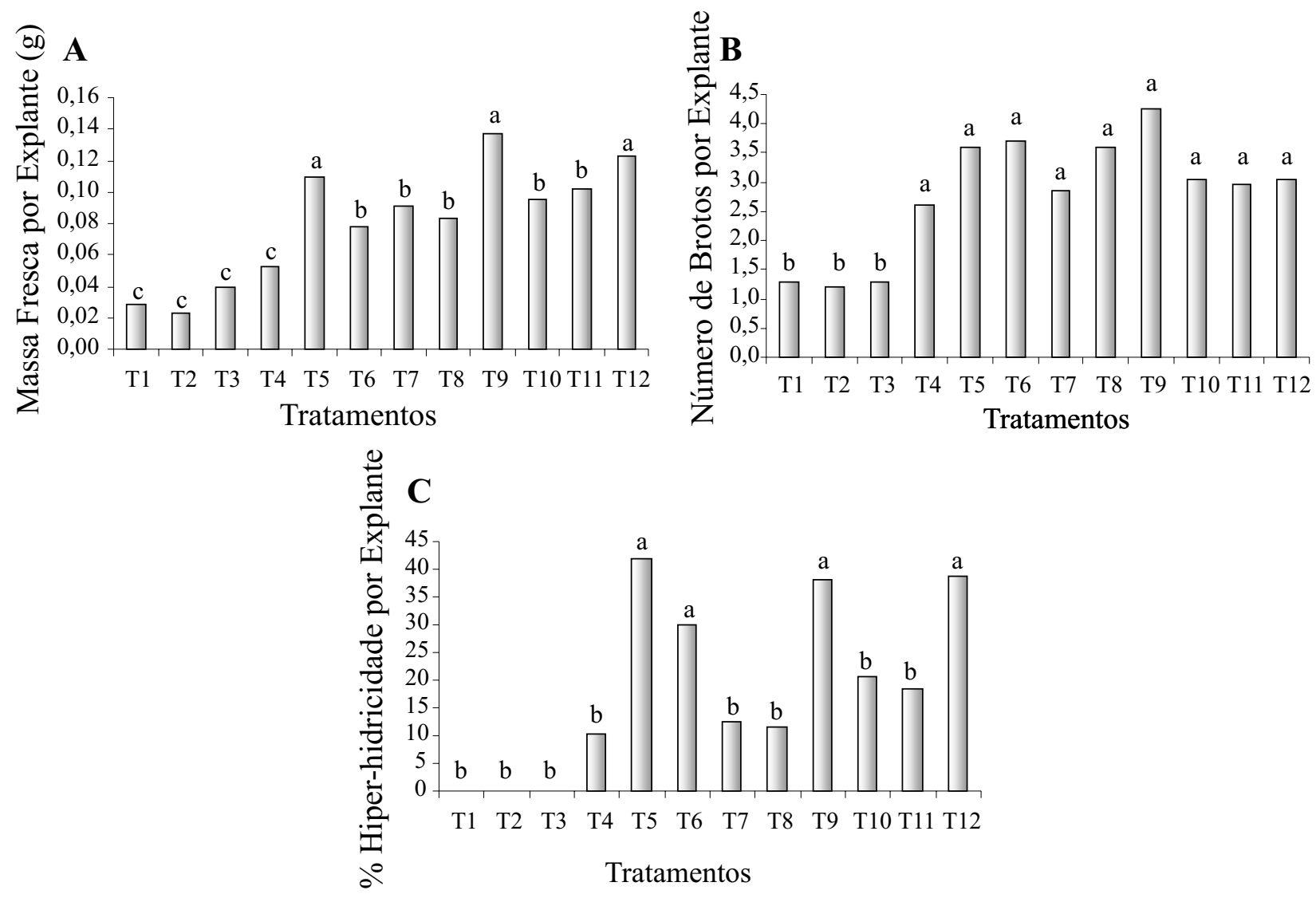

Figura 5 - Massa fresca (A), número de brotos (B) e percentual de hiper-hidricidade (C) por explantes nas diferentes combinações de BAP/ANA $(\mathrm{T} 1=0,0 / 0,0 ; \mathrm{T} 2=0,0 / 0,05 ; \mathrm{T} 3=0,0 / 0,5 ; \mathrm{T} 4=0,5 / 0,0 ; \mathrm{T} 5=0,5 / 0,05 ; \mathrm{T} 6=0,5 / 0,5$; $\mathrm{T} 7=1,0 / 0,0 ; \mathrm{T} 8=1,0 / 0,05 ; \mathrm{T} 9=1,0 / 0,5 ; \mathrm{T} 10=1,5 / 0,0 ; \mathrm{T} 11=1,5 / 0,05 ;$ e $\mathrm{T} 12=1,5 / 0,5 \mu \mathrm{M}$ de BAP/ANA) estudadas, aos 23 dias de cultivo em biorreatores de imersão temporária RITA ${ }^{\circledR}$ do clone de Eucalyptus grandis $x$ E. urophylla (C1). Tratamentos com letras iguais não diferiram significativamente a 5\% de probabilidade, pelo teste de Scott-Knott.

Figure 5 - Fresh weight (A), number of shoots (B) and hyperhydricity percentage (C) per explant in different combinations of BAP/NAA $(T 1=0.0 / 0.0, T 2=0.0 / 0.05, T 3=0.0 / 0.5, T 4=0.5 / 0.0, T 5=0.5 / 0.05, T 6=0.5 / 0.5, T 7=1.0 /$ $0.0, T 8=1.0 / 0.05, T 9=1.0 / 0.5, T 10=1.5 / 0.0, T 11=1.5 / 0.05$ and $T 12=1.5 / 0.5 \mu M$ BAP $/$ NAA) studied at 23 days of cultivation RITA ${ }^{\circledR}$ in temporary immersion bioreactors, of Eucalyptus grandis $x$ E. urophylla clone (C1). Treatments with same letters are not significantly different at 5\% probability by the Scott-Knott test.

a 0,0 $\mu \mathrm{M}$. Observou-se incremento do número de brotos nos tratamentos com o aumento da concentração de BAP até 1,0 $\mu \mathrm{M}$, enquanto onde a concentração era de 1,5 $\mu \mathrm{M}$ o número de brotos produzidos apresentou ligeiro decréscimo (Figura 5B). Não se verificou hiperhidricidade nos tratamentos onde a concentração de BAP foi de $0,0 \mu \mathrm{M}$ (T1, T2 e T3), sendo esses tratamentos semelhantes a T4, T7, T8, T10 e T11 (Figura 5C). O maior percentual de hiper-hidricidade (42\%) foi obtido no T5, tratamento que não diferiu estatisticamente do T6, T9 е T12.

\section{DISCUSSÃO}

Os biorreatores vêm surgindo como alternativa para a viabilidade da técnica de micropropagação de diversas espécies, especialmente por eliminar e, ou, automatizar algumas etapas do processo de produção. No entanto, trabalhos que tratam da avaliação de tipos e composições de meios de cultura em meio líquido ainda são escassos, principalmente focando a tecnologia de biorreatores em espécies lenhosas, razão pela qual a discussão deste trabalho se apoiou em estudos realizados em meio semissólido.

Revista Árvore, Viçosa-MG, v.35, n.6, p.1207-1217, 2011 


\subsection{Multiplicação em biorreator: meios de cultura MS e WPM}

Neste experimento, o meio MS apresentou melhores resultados de crescimento dos explantes, porém com maior ocorrência da hiper-hidricidade. O meio MS também se mostrou superior ao WPM, quanto ao crescimento e multiplicação das culturas, no cultivo de Amelanchier arborea (BRAND, 1993), de Cabralea canjerana (ROCHA et al., 2007) e de Acacia mearnsii (DISARZ; CORDER, 2009).

Assim como neste trabalho, o menor vigor e a coloração diferenciada dos explantes cultivados em meio WPM também foram observados em canjerana por Rocha et al. (2007), cujas folhas apresentavam clorose. Esses resultados podem estar relacionados ao fato de o meio WPM possuir apenas 45\% da força iônica total do meio MS (NUNES et al., 2002) e concentrações menores de nitrato, amônio e nitrogênio total (ROCHA et al., 2007). Em contrapartida, o meio WPM adicionado de reguladores de crescimento apresentou-se eficiente no cultivo de segmentos nodais de peroba-rosa (RIBAS et al., 2005).

As características massa fresca e número de brotos apresentaram a mesma tendência de crescimento entre os tratamentos. Nas condições estudadas, as duas características mostraram-se relacionadas, ou seja, quanto maior a massa fresca dos explantes, maior o número de brotos produzidos. Na micropropagação de cravo, Yadav et al. (2003) também observaram relação positiva entre massa fresca e multiplicação dos explantes.

Houve grande variação entre os explantes de um mesmo tratamento quanto às características avaliadas, ao número de brotos produzidos e à massa fresca, o que explica o fato de o erro-padrão da média ser elevado.

Apesar de o intervalo de imersão de 2 h ter promovido maior ganho em biomassa fresca e em número de brotos dos explantes, a hiper-hidricidade nesse manejo foi fator limitante. Reis et al. (2003) obtiveram incremento de oito vezes na massa fresca e 2,5 vezes no comprimento dos brotos de eucalipto cultivados por 22 dias em biorreator RITA ${ }^{\circledR}$, em meio MS com 0,5 $\mu \mathrm{M}$ de BAP e no manejo de 2 h, também com alta incidência de explantes hiper-hídricos. Correia et al. (1995), também em estudos com clones de Eucalyptus grandis x E. urophylla cultivados em meio JADS líquido, relataram sintomas de hiper-hidricidade após 28 dias de cultivo.
A hiper-hidricidade caracteriza-se morfologicamente por brotos alongados e espessos em diâmetro, entrenós mais curtos do que os das plantas normais, e as folhas se apresentam espessadas, frequentemente alongadas, enrugadas ou enroladas e quebradiças (GASPAR, 1991; ZIV, 1991). Essa desordem tem sido relatada, na maioria das vezes, apenas na fase de multiplicação.

As condições do cultivo in vitro, como alta umidade (GASPAR, 1991), fatores nutricionais como minerais e carboidratos, altos níveis de reguladores de crescimento, baixa irradiância e elevada disponibilidade de água no meio, são as maiores indutoras de desordens fisiológicas nas plantas, como a hiper-hidricidade (MAJADA et al., 2000). Com o emprego de biorreatores, o fator disponibilidade de água é ainda ampliado pelo uso do meio líquido, o qual está associado com alta mobilidade de água e, também, com alta umidade relativa no ambiente in vitro, induzindo, assim, a presença de sintomas da hiper-hidricidade (GASPAR et al., 1987).

\subsection{Multiplicação em biorreator: meios de cultura MS, QL e JADS}

O clone 1 apresentou resultados superiores de todas as características avaliadas, o que pode ser explicado pelo fato de ele ser considerado um clone de mais fácil propagação vegetativa, comparativamente ao clone 2 .

Essa diferença do cultivo in vitro entre genótipos, encontrada neste estudo, foi também relatada por Bravo et al. (2008) na influência do genótipo sobre a capacidade organogênica em progênies de E. grandis, quanto ao caráter proliferação in vitro; e em variações genéticas observadas entre e dentro de famílias de E. grandis, quanto à capacidade de formação de gemas (SOBROSA; CORDER, 2003), assim como influenciando o desenvolvimento in vitro de gemas de clones de Eucalyptus grandis $\mathrm{x}$ E. urophylla (CORREIA et al., 1995).

A resposta ao tipo e composição do meio de cultura varia não somente de acordo com a espécie, mas entre genótipos de uma mesma espécie e até entre explantes de um mesmo genótipo, que apresentam demandas específicas (SOUZA et al., 2006). Correia et al. (1995) verificaram a importância da especificidade do meio de cultura para cada material genético, quando se deseja a proliferação de gemas com uniformidade e vigor. Além disso, fatores ambientais como a aeração do meio de cultura e o controle de seu fluxo, a qualidade e intensidade 
da luz e o fotoperíodo podem influenciar no crescimento e desenvolvimento dos explantes, assim como a idade ontogenética e o estado de maturação da cultura. Dessa maneira, fica clara a necessidade de ajuste do protocolo de micropropagação, de acordo com o material genético de interesse.

Ao contrário do que foi observado neste trabalho, em que o meio MS apresentou tendência de crescimento superior em relação aos demais meios estudados, Glocke et al. (2006) observaram crescimento mais vigoroso dos brotos em meio WPM e QL na micropropagação de material juvenil de Eucalyptus erythronema x E. stricklandii, em comparação com outros meios, como o MS. Já Borges (2009) avaliou a diferença entre os meios MS e JADS na multiplicação de clones de Eucalyptus urophylla x E. globulus e Eucalyptus grandis x E. globulus e encontrou tendência de melhores resultados no meio MS, observando também que esse meio produziu brotações mais alongadas e com folhas maiores. No entanto, apesar da tendência de superioridade do meio MS, o meio JADS apresentou resultados positivos na multiplicação desses clones. Esse autor também observou ocorrência de hiper-hidricidade em poucos explantes no meio MS, o que não foi visto no meio JADS.

\subsection{Multiplicação em biorreator: relação BAP/ANA}

O incremento em produtividade, tanto em massa fresca quanto em número de brotos, foi considerado baixo neste experimento, em comparação com os demais ensaios anteriores, podendo ser explicado pelo curto período de cultivo e pelo tamanho inicial dos explantes, que apresentavam, em média, 0,007 g de massa fresca.

A combinação 1,0/0,5 $\mu \mathrm{M}$ de BAP/ANA (T9) foi a que apresentou maiores médias em massa fresca e número de brotos. A massa fresca e o número de brotos por explantes tenderam a aumentar com crescentes concentrações de BAP e depois a diminuir nas concentrações mais elevadas desse regulador. Graça et al. (2001) observaram maior proliferação de brotos de E. dunnii na concentração de $1 \mu \mathrm{M}$ de BAP, apresentando relação inversa entre o número de brotações e a concentração de BAP. Esse mesmo comportamento foi relatado por Andrade et al. (2006) na multiplicação de E. grandis sob o estímulo de BAP, observando que concentrações elevadas dessa citocinina promovem ação inibitória na multiplicação de Eucalyptus. Muitos autores relataram esse comportamento em espécies de eucalipto (DEL PONTE et al., 2001; BRONDANI,
2007). O efeito da concentração dos reguladores de crescimento varia de acordo com a espécie (GRATTAPAGLIA; MACHADO, 1998).

Em termos gerais, este experimento apresentou baixo percentual de hiper-hidricidade dos explantes, variando de 0 a 41,9\%, em comparação com o estudo discutido no item 4.1, que utilizou o mesmo tipo de explante inicial e atingiu valores próximos a 100\% de hiper-hidricidade. Essa diferença também pode ser explicada pelo curto período de cultivo, pois foi observado no decorrer desses estudos que a hiperhidricidade, assim como o ganho em biomassa fresca e a produtividade, foram mais intensos a partir do $20^{\circ}$ dia de cultivo.

A heterogeneidade no desenvolvimento dos explantes, em todas as características avaliadas, foi alta. O mesmo foi observado por Correia et al. (1995), que encontraram grande variação na multiplicação de gemas entre os explantes, dentro e entre clones de Eucalyptus grandis x E. urophylla, cultivados em meio de cultura líquido e sólido. A fonte de variação no crescimento in vitro entre os explantes pode estar relacionada com o tamanho e as características morfológicas do explante, como número de pares de folhas e diâmetro do caule, além das idades cronológica, fisiológica e ontogenética da cultura.

\section{CONCLUSÕES}

O meio de cultura MS e a frequência de imersão a cada $2 \mathrm{~h}$ foram os tratamentos que promoveram melhor resposta de crescimento em relação à massa fresca e à produtividade dos explantes dos clones de Eucalyptus grandis x E. urophylla.

O clone C1 foi superior ao clone C2 quanto às características de crescimento avaliadas.

A combinação 1,0 $\mu \mathrm{M}$ de BAP com 0,5 $\mu \mathrm{M}$ de ANA foi a que apresentou maiores médias em relação à massa fresca e ao número de brotos.

De modo geral, as culturas apresentaram alto percentual de hiper-hidricidade, sendo essa desordem ainda fator limitante nas condições deste estudo para a micropropagação em biorreator de imersão temporária de clones de Eucalyptus.

Mais estudos são necessários para o ajuste de protocolos de cultivos de eucalipto que viabilizem a técnica de micropropagação em biorreatores.

Revista Árvore, Viçosa-MG, v.35, n.6, p.1207-1217, 2011 


\section{REFERÊNCIAS}

AITKEN-CHRISTIE, J.; SINGH, A. P.; DAVIES, H. Multiplication of meristematic tissue: a new tissue culture system for radiata pine. In: HANOVER, J. W.; KEATHLEY, D. E. Genetic manipulation of wood plants. New York: Plenum, 1988. p.413-432.

ANDRADE, W. F.; ALMEIDA, M.; GONÇALVES, A. N. Multiplicação in vitro de Eucalyptus grandis sob estímulo com benzilaminopurina. Pesquisa Agropecuária Brasileira, v.41, n.12, p.1715-1719, 2006.

BORGES, S. R. Micropropagação e enraizamento de miniestacas de clones híbridos de Eucalyptus globulus. 2009. 60 f. Dissertação (Mestrado em Ciência Florestal) Universidade Federal de Viçosa, Viçosa, MG, 2009.

BRAND, M. H. Agar and ammonium nitrate influence hyperhydricity, tissue nitrate and total nitrogen content of serviceberry (Amelanchier arborea) shoots in vitro. Plant Cell, Tissue and Organ Culture, v.35, n.3, p.203-209, 1993.

BRAVO, C. D. V. et al. Controle genético da regeneração in vitro em progênies de Eucalyptus grandis. Ciência Rural, v.38, n.8, p.2181-2185, 2008.

BRONDANI, G. E. et al. Estabelecimento, multiplicação e alongamento in vitro de Eucalyptus benthamii Maiden \& Cambage x Eucalyptus dunnii Maiden. Revista Árvore, v.33, n.1, p.11-19, 2009.

CASTRO, D. R.; GONZÁLEZ, O. J. Micropropagación de eucalipto (Eucalyptus grandis Hill ex Maiden) en el sistema de inmersión temporal. Agricultura Técnica, v.62, n.1, p.68-78, 2002.

CORREIA, D. et al. Efeito do meio de cultura líquido e sólido no desenvolvimento de gemas de Eucalyptus grandis x Eucalyptus urophylla na multiplicação in vitro. IPEF, n. 48/49, p.107-116, 1995.

DEL PONTE, E. M. et al. Multiplicação e enraizamento in vitro de Eucalyptus globulus subsp. globulus Labill. Revista Árvore, v.25, n.1, p.1-8, 2001.
DISARZ, R.; CORDER, M. P. M. Multiplicação de gemas axilares de acacia mearnsii de Wild. sob diferentes meios de cultura. Revista Árvore, v.33, n.4, p.599-606, 2009.

ETIENNE, H. et al. Bioreactors in coffee micropropagation. Brazilian Journal of Plant Physiology, v.18, n.1, p.45-54, 2006.

ETIENNE, H. et al. Improvement of somatic embryogenesis in Hevea brasiliensis using the temporary immersion technique. In Vitro Cellular and Developmental Biology Plant, v.33, n.1, p.81-87, 1997.

GASPAR, T. et al. Vitrification: morphological, physiological and ecological aspects. In: BONGA, J. M.; DURZAN, D. J. (Ed.). Cell and tissue culture in forestry. Dordrecht: Martinus Nijhoff Publishers, 1987. v.1. p.152-166.

GASPAR, T. Vitrification in micropropagation. In: BAJAJ, Y. P. S. (Ed.). Biotechnology in agriculture and forestry - High-tech and micropropagation I. Berlin: Springer, 1991. v.17. p.116-126.

GLOCKE, P. et al. Micropropagation of juvenile tissue of Eucalyptus erythronema x Eucalyptus stricklandii cv. 'Urrbrae Gem'. In Vitro Cellular and Developmental Biology Plant, v.42, v.1, p.139-143, 2006.

GRAÇA, M. E. C. et al. Efeitos das citocininas benzilamino purina e thidiazuron, na multiplicação "in vitro" de brotações de Eucalyptus dunnii Maid. Boletim de Pesquisa Florestal, n.43, p.107-112, 2001.

GRATTAPAGLIA, D.; MACHADO, M.A. Micropropagação. In: TORRES, A. C.; CALDAS, L. S.; BUSO, J. A. (Eds.). Cultura de tecidos e transformação genética de plantas. Brasília: Embrapa-SPI/EMBRAPA-CNPH, 1998. v.1. p.183-260.

GUPTA, P. K.; TIMMIS, R. Mass propagation of conifer trees in liquid cultures-progress towards commercialization. Plant Cell, Tissue and Organ Culture, v.81, p.339-346, 2005. 
LLOYD, G.; McCOWN, B. Commercially feasible micropropagation of mountain laurel, Kalmia latifolia, by use of shoot tip culture.

Combined Proceedings of the International Plant Propagators Society, v.30, p.421-426, 1980.

MAJADA, J. P. et al. Impact of culture vassel ventilation on the anatomy and morphology of micropropagated carnation. Plant Cell, Tissue and Organ Culture, v.63, p.207-214, 2000.

McALISTER, B. et al. Use of the temporary immersion bioreactor system (RITA) for production of commercial Eucalyptus clones in Mondi Forest (SA). Plant Cell, Tissue and Organ Culture, v.81, p.347-358, 2005.

MURASHIGE, T.; SKOOG, F. A revised medium for rapid growth and bioassays with tobacco tissue cultures. Physiologia Plantarum, v.15, n.3, p.473-497, 1962.

NUNES, E. C. et al.. In vitro culture of Cedrela fissilis Vellozo (Meliaceae). Plant Cell, Tissue and Organ Culture, v.70, p.259-268, 2002.

QUOIRIN, M.; LEPOIVRE, P. Improved medium for in vitro culture of Prunus sp. Acta

Horticulturae, v.78, p.437-442, 1977.

REIS, J. P. et al. Micropropagação de eucalipto no sistema de imersão temporária. In: CONGRESSO BRASILEIRO DE CULTURA DE TECIDOS DE PLANTAS, 1., 2003, Lavras. Anais...

Lavras:2003. p.276.

RIBAS, L. L. F. et al. Micropropagação de Aspidosperma polyneuron (peroba-rosa) a partir de segmentos nodais de mudas juvenis. Revista Árvore, v.29, n.4, p.517-524, 2005.
ROCHA, S. C. et al. Micropropagação de Cabralea canjerana. Revista Árvore, v.31, n.1, p.43-50, 2007.

SANTOS-SEREJO, J. A. et al. Meios nutritivos para micropropagação de plantas. In: SOUZA, A. S.; JUNGHANS, T. G. (Org.). Introdução à micropropagação de plantas. Cruz das Almas: Embrapa Mandioca e Fruticultura Tropical, 2006. p.79-98.

SOBROSA, R. C.; CORDER, M. P. M. Efeito do genótipo sobre o potencial para produção de gemas e raízes adventícias em Eucalyptus grandis Hill ex Maiden in vitro. Floresta e

Ambiente, v.10, n.1, p.58-68, 2003.

SOUZA, F. V. D. et al. Micropropagação. In: SOUZA, A. S.; JUNGHANS, T. G. (Org.).

Introdução à micropropagação de plantas. Cruz das Almas: Embrapa Mandioca e Fruticultura Tropical, 2006. p.38-52.

YADAV, M. K.; GAUR, A. K.; GARG, G. K. Development of suitable protocol to overcome hyperhydricity in carnation during micropropagation. Plant Cell, Tissue and Organ Culture, v.72, p.153-156, 2003.

ZIV, M. The control of biorreactor environment for plant propagation in liquid culture. Acta Horticulturae, v.393, n.1, p.25-38, 1995.

ZIV, M. Vitrification: morphological and physiological disorders of in vitro plants. In: DEBERGH, P. C.; ZIMMERMAN, R. H. (Eds.). Micropropagation, technology and aplication. Dordrecht: Kluwer Academic, 1991. p.45-69. 
